\title{
KEARIFAN LOKAL DALAM MEMBANGUN KETAHANAN PANGAN PETANI
}

\author{
Intan Purnama Sari ${ }^{1}$, Dr. Ahmad Zuber, S.Sos., D.E.A ${ }^{2}$ \\ Program Studi Sosiologi Fakultas Ilmu Sosial dan Politik \\ Universitas Sebelas Maret Surakarta Indonesia \\ Email: intanpurnamasari240@gmail.com
}

\begin{abstract}
The purpose of this study was to find out how local wisdom in the agricultural production system in building food security of farmers in Pacarejo Village. The study uses qualitative methods with a case study approach. The results showed that the agricultural production system carried out by farmers is the result of adaptation of the natural environment and farming experience that has been carried out for many years. Through its local wisdom, farmers have strategies to develop family food security. The supporting factor is the existence of farmer groups as a forum for empowering farmers in discussing agricultural issues, while the limiting factor is the limited availability of water. Through its local wisdom, farmers in Pacarejo Village can build family food security.
\end{abstract}

Keywords: local wisdom, food security, agriculture.

Abstrak: Tujuan penelitian ini untuk mengetahui bagaimana kearifan lokal dalam sistem produksi pertanian dalam membangun ketahanan pangan petani di Desa Pacarejo. Penelitian menggunakan metode kualitatif dengan pendekatan studi kasus. Hasil penelitian menunjukkan bahwa sistem produksi pertanian yang dilakukan oleh petani merupakan hasil dari adaptasi lingkungan alam serta pengalaman bertani yang telah dilakukan bertahuntahun lamanya. Melalui kearifan lokalnya, petani memiliki strategi-strategi yang dilakukan untuk membangun ketahanan pangan keluarga. Faktor pendukung adanya kelompok tani sebagai wadah pemberdayaan petani dalam membahas masalah pertanian, sedangkan faktor penghambat adalah terbatasnya ketersediaan air. Melalui kearifan lokalnya, petani di Desa Pacarejo dapat membangun ketahanan pangan keluarga.

Kata kunci: kearifan lokal, ketahanan pangan, pertanian.

\section{PENDAHULUAN}

Pertanian merupakan suatu kesatuan yang tak terpisahkan dari pedesaan. Pertanian adalah salah satu komponen utama dalam menopang kehidupan. Pertanian mempunyai peranan penting, salah satunya adalah sebagai penyedia kebutuhan pangan yang sangat diperlukan oleh masyarakat untuk menjamin ketahanan pangan. Semakin tinggi pertumbuhan populasi manusia maka kebutuhan terhadap pangan juga semakin meningkat. Menurut data statistik ketahanan pangan tahun 2016, komoditas pangan penting terdiri dari dua, yaitu (1) pangan nabati: padi (gabah), jagung, kedelai, kacang tanah, ubi kayu, ubi jalar, sayur, buah-buahan, minyak goreng sawit, dan gula putih; (2) pangan hewani: daging sapi, daging ayam, telur unggas, susu, dan ikan (BKP, 2016).

Ketersediaan bahan pangan di suatu daerah tertentu yang berkurang akan menimbulkan berbagai permasalahan pangan seperti: kelaparan, kerawanan pangan dan 
kerentanan pangan. Bahan pangan strategis yang menghasilkan unsur-unsur gizi dalam makanan sangat dibutuhkan oleh manusia seperti karbohidrat, protein, mineral, lemak dan vitamin. Bahan pangan tersebut menjadi prioritas dalam program peningkatan ketahanan pangan (Sukari et al., $2016: 2$ ).

Pertanian tradisional yang telah berkembang dalam masyarakat selama ini seharusnya dapat ditarik kesimpulan bahwa dengan menggunakan sistem tersebut masyarakat petani tradisional telah berhasil menyediakan makanan bagi satu generasi petani ke generasi berikutnya. Kearifan lokal adalah aspek paling penting dalam sistem pertanian tradisional. Kearifan lokal sering diartikan sebagai pengetahuan setempat (local knowledge) yang di dalamnya terkandung pengetahuan serta berbagai strategi dalam menjawab berbagai permasalahan yang berkaitan dengan lingkungan hidup, pemenuhan kebutuhan pangan, serta strategi adaptasi masyarakat dalam menghadapi perubahan lingkungan alam dan sosial.

Bentuk lahan pertanian di Indonesia terbagi menjadi dua jenis yaitu lahan basah dan lahan kering. Wilayah Gunungkidul merupakan salah satu sebaran lahan kering. Lahan kering selain berpotensi meningkatkan ketahanan pangan juga mempunyai beberapa permasalahan seperti rendahnya kadar air tanah, besarnya limpasan permukaan, tingginya nilai sedimentasi. Permasalahan-permasalahan ini dapat menyebabkan berkurangnya produksi tanaman pangan, menurunkan kualitas air, hingga kekeringan (Khalimi dan Zaenal, 2018: 721).

Wilayah Kabupaten Gunungkidul merupakan salah satu kabupaten di DIY dengan lahan pertanian yang didominasi oleh lahan kering. Dengan kondisi seperti itu, petani di lahan kering memiliki kearifan lokal yang berbeda dengan petani di lahan basah. Lahan pertanian di daerah basah seperti sawah sangat terjangkau dengan jaringan irigasi teknis, sementara di lahan kering tidak. Perbedaan kondisi tersebut membentuk kearifan lokal yang mencerminkan hasil adaptasi terhadap lingkungan alam dan sosial yang ada. Tujuan penelitian ini untuk mengetahui bagaimana kearifan lokal dalam sistem produksi pertanian, strategi petani dalam membangun ketahanan pangan serta faktor pendukung dan faktor penghambat kearifan lokal dalam membangun ketahanan pangan petani di Desa Pacarejo.

Penelitian akan dianalisis menggunakan Teori Fungsionalisme Struktural Talcott Parsons mengenai konsep AGIL yaitu Adaptation, Goal attainment, Integrations, dan Latency. Adaptasi (adaptasi), sistem harus mengatasi kebutuhan situasional yang datang dari luar. Ia harus beradaptasi dengan lingkungan dan menyesuaikan lingkungan dengan kebutuhan-kebutuhannya. Goal attainment (pencapaian tujuan), sistem harus mendefinisikan dan mencapai tujuan-tujuan utamanya. Integration (integrasi), sistem harus mengatur hubungan bagian-bagian yang menjadi komponennya dan Latency (pemeliharaan pola), dimana sistem harus melengkapi, memelihara dan memperbaharui motivasi individu dan pola-pola budaya yang menciptakan dan mempertahankan motivasi tersebut (Ritzer dan Goodman, 2010 : 121).

\section{METODE PENELITIAN}

Penelitian dilakukan di Desa Pacarejo, Kecamatan Semanu, Kabupaten Gunungkidul. Penelitian ini menggunakan metode kualitatif dengan pendekatan studi kasus. Metode penelitian ini menggunakan kualitatif guna untuk mengetahui kondisi yang sebenarnya mengenai kearifan lokal dalam membangun ketahanan pangan petani di Desa Pacarejo. Penelitian ini menggunakan pendekatan studi kasus dengan keadaan menarik, yaitu dengan kondisi fisik lahan pertanian yang kering petani mampu mencukupi kebutuhan 
pangan utama keluarga. Pemilihan informan dalam penelitian ini menggunakan teknik purposive sampling, dengan tujuan agar dapat diperoleh sampel yang memenuhi kriteria. Sugiyono (2008) menjelaskan bahwa Purposive sampling yaitu sampel yang ditarik dengan pertimbangan-pertimbangan tertentu sesuai dengan tujuan dan maksud penelitian. Individuindividu yang dipilih adalah individu yang dianggap cukup mengetahui permasalahan yang hendak diteliti serta memenuhi kriteria yang telah ditetapkan oleh peneliti. Teknik pengambilan data menggunakan data primer yakni berupa wawancara langsung dan data sekunder diperoleh dari dokumen dan foto. Teknik pengumpulan data menggunakan observasi, wawancara, hingga dokumentasi. Validates data dalam penelitian menggunakan triangulasi data dengan membandingkan satu sumber dengan sumber lain yang berbeda.

\section{HASIL DAN PEMBAHASAN}

A. Kearifan lokal dalam produksi pertanian

Wilayah Desa Pacarejo yang merupakan dataran tinggi kering dengan bentuk wilayahnya bergelombang sampai berbukit. Pengelolaan lahan yang dilakukan oleh petani di Desa Pacarejo merupakan hasil dari adaptasi lingkungan alam serta pengalaman bertani yang telah dilakukan bertahun-tahun lamanya. Pengelolaan lahan dalam sistem produksi pertanian terutama pada tanaman pangan di lahan kering sangat diperlukan dan perlu mendapat perhatian yang lebih agar mendapat hasil yang lebih baik atau maksimal. Untuk itu, ada beberapa tahapan yang perlu dilakukan dan diperhatikan petani dalam sistem produksi pertanian, yaitu pengolahan lahan/tanah, pemupukan, penanaman, pemeliharaan tanaman serta penanganan hasil.

\section{Pengolahan Lahan}

Petani Desa Pacarejo memanfaatkan lahannya yang berupa tegalan untuk pertanian padi dan palawija. Jenis tanah di Desa Pacarejo pada umumnya adalah komplek latosol dan mediteran merah dengan bebatuan cadas. Sistem pengolahan lahan yang dilakukan petani Desa Pacarejo mayoritas menggunakan sistem pertanian yang telah ada secara turun temurun, meskipun sudah ada inovasi dalam sistem pertanian yang telah dibina oleh Balai Penyuluh Pertanian (BPP) melalui PPL (Penyuluh Pertanian Lapangan). Hal itu karena kondisi lahan pertanian di Desa Pacarejo yang kering dan keras, petani hanya melakukan pengolahan lahan secara tradisional. Pengolahan lahan dilakukan untuk membersihkan lahan dari gulma. Dengan kondisi lahan yang keras tidak memungkinkan lahan untuk diolah atau dibajak menggunakan traktor.

Pengolahan lahan dengan cara tradisional ini, memiliki segi positif dimana tidak membutuhkan biaya besar karena dilakukan dengan cara manual dengan tenaga sendiri ataupun bantuan keluarga. Pengolahan yang dilakukan biasanya mengandalkan air hujan agar tanah tidak terlalu keras saat diolah. Setelah lahan dibersihkan dilanjutkan dengan mencangkul lahan dengan menggunakan alat alat seperti cangkul, gathul maupun lengis. Pencangkulan lahan biasanya dilakukan di tanah yang tidak terlalu keras dan dilanjutkan dengan pemberian pupuk kandang sebagai pupuk dasar dalam pengolahan lahan. Ukuran pemberian pupuk kandang tergantung luas lahan dan pemilikan pupuk. Pupuk kandang yang dimaksud ada dua yaitu dari kotoran sapi dan kotoran ayam. Pupuk kandang terutama kotoran sapi bagi petani Desa Pacarejo merasa tercukupi karena hampir semua petani memiliki dan memelihara ternak sapi. 
Sebelum memulai penyebaran benih di lahan tegalan yang telah diolah, petani di Desa Pacarejo biasanya melakukan sebuah tradisi yang telah ada secara turun temurun. Tradisi tersebut dinamakan tradisi wiwitan. Tradisi ditujukan dan dilakukan sebagai bentuk kepercayaan petani kepada Dewi Sri. Tradisi dilakukan dengan mengundang tetangga dekat atau istilahnya kenduri dengan sajian tumpeng dan kelengkapannya. Pemilihan waktu sangat penting dalam melaksanakan tradisi wiwitan ini, karena waktu yang dipilih tidak boleh sembarangan. Biasanya, petani menggunakan hari baik maupun weton hari kelahiran.

\section{Jenis tanaman dan cara menanamnya}

Tanaman yang ditanam oleh petani di Desa Pacarejo adalah padi dan palawija. Padi yang ditanam ada beberapa jenis, seperti padi gogo (pari jawa) seperti mandhel dan wulu putih, beras ketan, dan padi usia pendek seperti IR64, Ciherang, Segreng dan lainlain. untuk palawija yang ditanam berupa jagung, kacang tanah, kedelai, ubi kayu, dan lan-lain. Dengan kondisi lahan kering, pertanian padi yang dilakukan di Desa Pacarejo hanya bisa dilakukan satu kali dalam setahun, yakni pada musim hujan pertama atau musim tanam pertama. Pertanian padi yang dilakukan menggunakan sistem tadah hujan, sehingga pertanian padi sangat bergantung pada air hujan. Setelah pertanian padi kemudian dilanjutkan dengan pertanian palawija maupun holtikultura.

Keterbatasan air menyebabkan petani di Desa Pacarejo memilih jenis tanaman padi yang memiliki masa tanam pendek. Seleksi benih yang dilakukan oleh petani di Desa Pacarejo ada yang disiapkan sendiri dari hasil panen sebelumnya dan ada yang membeli benih yang biasanya program benih bersubsidi dari Dinas Pertanian. Mayoritas cara tanam padi yang dilakukan petani di Desa Pacarejo adalah dengan cara ditonjo menggunakan alat tonjo. Alat tonjo merupakan alat yang terbuat dari batang pohon yang dibuat runcing salah satu sisinya bahkan ada yang dilapisi dengan besi. Bagian yang runcing tersebut digunakan untuk membuat lubang di tanah yang sudah diolah kemudian dilanjut dengan menaruh benih dilubang tersebut.

Tenaga yang digunakan saat penanaman yang dilakukan oleh petani di Desa Pacarejo adalah tenaga manusia, baik tenaga sendiri maupun tenaga orang lain dalam artian menggunakan buruh tani. Namun, masih ada juga yang menanam secara gotong royong yakni secara bergantian dari satu petani ke petani yang lain. dengan bergotong royong bergantian.. Untuk tenaga buruh tani di Desa Pacarejo rata-rata upah yang diterima sebesar Rp 50.000/hari.

\section{Pola tanam dan pemeliharaan tanaman}

Pola tanam pada umumnya terbagi menjadi dua yaitu (1) pola tanam tunggal (monokultur), merupakan pola tanam yang menanam tanaman sejenis atau satu komoditas pada suatu lahan pertanian; (2) pola tanam ganda (polikultur), merupakan suatu pola penanaman dengan membudidayakan lebih dari satu jenis komoditas tanaman pada suatu lahan pertanian (Anonim, 2017).

Berdasarkan pengertian pola tanam diatas, petani di Desa Pacarejo dalam menanam tanaman kebanyakan menggunakan pola tanam ganda (polikultur). Pola tanam tersebut merupakan bagian dari pengetahuan petani yang telah didapat secara turun-temurun. Pola tanam yang dilakukan oleh petani di Desa Pacarejo biasa disebut tumpang sari, karna dalam satu tahun tanaman yang ditanam dilahan lebih dari satu jenis. Misalnya tanaman utama padi yang ditanam dibarengi dengan tanaman jagung dan ketela dalam satu lahan pertanian. 
Selain pola tanam secara tumpangsari, ada juga pola tanam tajarwo. Sistem tajarwo adalah sistem tanam jajar legowo dimana pola tanam yang dilakukan dengan mengosongkan satu baris tanaman kemudian diselingi baris tanaman lagi. Pola tanam tajarwo ini sudah mulai berkembang di Petani di Desa Pacarejo dan menjadi anjuran dari Dinas Pertanian dan Pangan Gunungkidul melalui sosialiasi yang dilakukan oleh PPL. Alasan petani di Desa Pacarejo lebih memilih pola tanam secara tumpangsari karena dapat memanfaatkan lahan semaksimal mungkin serta hasil hasil yang diperoleh ketika panen bermacam-macam tidak hanya satu jenis komoditas saja. Dengan tumpang sari, ketika terjadi kegagalan panen pada satu komoditas masih dapat memanen komoditas yang lain. Sehingga, melalui tumpang sari dapat meminimalisir adanya resiko kegagalan yang tinggi dalam usaha pertanian.

Selanjutnya, pembersihan rerumputan dilakukan dengan cara mencabut rumput disekitar tanaman atau dengan istilah petani setempat dangir terutama pada tanaman padi. Dangir yang dilakukan menggunakan alat yakni gathul. Untuk petani yang memiliki lahan luas, biasanya proses dangir atau penyiangan rumput dilakukan dengan menggunakan tenaga buruh tani. Dalam penggunaan pupuk, pihak pemerintah Desa Pacarejo lebih menekankan kepada penggunaan pupuk organik, sesuai dengan program pemerintah yang berusaha menghimbau agar petani dapat mengurangi penggunaan pupuk kimia yang berdampak merusak kesuburan tanah.

Untuk pengendalian hama pada tanaman padi, petani di Desa Pacarejo biasanya menggunakan cara-cara tradisional turun temurun serta menggunakan obat pestisida sesuai dengan anjuran PPL. Untuk pengendalian secara tradisional, bahan-bahan yang digunakan berasal dari bahan alami yang kemudian diramu sendiri. Alasan petani menggunakan cara tradisional dan alami ini adalah untuk menjaga kualitas tanah dan tanaman agar tetap terjaga. Penggunaan pestisida dilakukan hanya jika hama yang menyerang tanaman sudah tidak dapat diatasi dengan cara alami sebelumnya.

\section{Penanganan hasil pertanian}

Alat yang digunakan dalam proses panen tanaman padi yang dilakukan petani di Desa Pacarejo masih menggunakan peralatan manual seperti sabit untuk memotong batang padi. tanaman padi yang sudah dipotong kemudian dibawa pulang untuk dirontokkan. Rata-rata petani di Desa Pacarejo memiliki alat perontok sendiri disetiap rumah. Hal itu dikarenakan batang padi yang sudah dirontokkan dijadikan untuk pakan ternak sapi. Hal itu juga berlaku pada tanaman jagung, dimana jagung yang dipanen juga akan dipotong batangnya untuk dibawa pulang sebagai pakan ternak sapi mereka.

Petani di Desa Pacarejo memiliki satu ruangan atau lumbung untuk menyimpan hasil panen pertaniannya. Hasil panen yang sudah dibagor kemudian disimpan di lumbung pribadi di dalam rumah. Selain lumbung, petani menyimpan hasil pertanian didalam gledhek atau lemari khusus untuk menghindari serangan tikus. Tenaga yang digunakan pada waktu panen adalah tenaga orang baik tenaga keluarga, sambatan, maupun buruh tani. Untuk petani yang lahannya sedikit biasanya menggunakan tenaga keluarga dalam melakukan proses panen. Untuk petani dengan lahan yang luas mengandalkan tenaga buruh tani dengan upah harian sebesar Rp 60.000 sampai Rp 75.000 per hari. Hal itu dikarenakan karena setiap musim panen yang dilakukan akan membutuhkan tenaga buruh tani, sedangkan disisi lain buruh tani juga memiliki lahan yang harus dipanen.

Petani di Desa Pacarejo masih mengadakan tradisi yang dilakukan saat panen. Namun, tradisi ini sudah jarang dilakukan dan hanya dilakukan oleh petani yang masih 
membudidayakan tanaman padi jawa. Hal itu dilakukan sebagai bentuk rasa syukur kepada Dewi Sri. Tradisi diawali dengan petani mengambil beberapa tanaman padi yang bagus untuk dibawa pulang. Hal itu dinamakan tradisi nglengani sebagai syarat dalam tradisi adat jawa mereka. Setelah itu petani mengadakan kenduri dengan membuat tumpeng dan kelengkapanya. Tradisi ini hanya dilakukan oleh petani didalam rumah dengan mengundang sesepuh atau tetua adat. Selain itu, masyarakat di Desa Pacarejo juga masih merayakan tradisi setelah masa panen yang dilakukan. Tradisi yang dilakukan oleh masyarakat petani secara bersama-sama setelah panen raya ini dinamakan dengan bersih dusun. Bersih dusun dilaksanakan sebagai tanda terima kasih masyarakat petani kepada Tuhan. Tradisi ini dirayakan dengan berbagai acara kesenian.

Dari penjelasan sebelumnya, maka strategi membangun ketahanan pangan yang dilakukan petani di Desa Pacarejo dapat disederhanakan dalam bentuk tabel berikut:

Tabel 1. Kearifan Lokal dalam Sistem Produksi Pertanian

\begin{tabular}{|c|c|c|}
\hline No. & $\begin{array}{l}\text { Sistem Produksi } \\
\text { Pertanian }\end{array}$ & Kearifan Lokal \\
\hline 1. & $\begin{array}{l}\text { Pengolahan } \\
\text { Lahan }\end{array}$ & $\begin{array}{l}\text { 1) Pengolahan lahan secara turun temurun } \\
\text { 2) Pemupukan dasar menggunakan pupuk kandang } \\
\text { 3) Masih terdapat tradisi wiwitan }\end{array}$ \\
\hline 2. & $\begin{array}{lr}\text { Jenis } & \text { Tanaman } \\
\text { dan } & \text { Cara } \\
\text { Menanamnya }\end{array}$ & $\begin{array}{l}\text { 1) Tanaman utama padi dan palawija, menghindari } \\
\text { jenis tanaman yang memiliki usia lama. } \\
\text { 2) Cara tanam dengan alat berupa tonjo dan gathul. } \\
\text { 3) Menggunakan tenaga keluarga, buruh tani } \\
\text { maupun bergantian secara gotong royong }\end{array}$ \\
\hline 3. & $\begin{array}{l}\text { Pola Tanam dan } \\
\text { Perawatan }\end{array}$ & $\begin{array}{l}\text { 1) Pola tanam secara tumpangsari } \\
\text { 2) Perawatan dangir dilakukan dengan tenaga orang } \\
\text { dan pakai alat gathul } \\
\text { 3) Pemupukan dengan pupuk kandang dan pupuk } \\
\text { kimia } \\
\text { 4) Pengendalian hama secara turun temurun } \\
\text { menggunakan bahan-bahan tradisional dan secara } \\
\text { modern menggunakan obat pestisida }\end{array}$ \\
\hline
\end{tabular}




\begin{tabular}{|c|c|c|}
\hline 4. & Penanganan Hasil & $\begin{array}{l}\text { 1) Terdapat tradisi nglengani saat panen dan tradisi } \\
\text { bersih dusun setelah panen raya } \\
\text { 2) Setiap rumah memiliki alat pemotong padi } \\
\text { masing-masing karena } \\
\text { 3) Penyimpanan hasil pertanian berupa bagor, pogo, } \\
\text { lumbung dan gledek. }\end{array}$ \\
\hline
\end{tabular}

Sumber: Data Primer, 2020

B. Strategi dalam membangun ketahanan pangan petani

1. Ketersediaan pangan

Ketersediaan bahan pangan utama seperti padi sangat penting dan mendasar bagi para petani karena beras merupakan bahan makan pokok bagi seluruh warga masyarakat. Dari hasil produksi yang dilakukan oleh petani di Desa Pacarejo bahkan dapat mencukupi kebutuhan pangan sampai panen berikutnya. Artinya, kebutuhan pangan keluarga tercukupi dengan baik. Sumber ketersediaan pangan lainnya adalah binatang ternak. Masyarakat di Desa Pacarejo mayoritas memiliki hewan ternak baik sapi, kambing, dan ayam. Ternak bagi masyarakat Pacarejo merupakan tabungan keluarga. Apabila ada rencana pengeluaran dalam jumlah relatif besar, petani akan menjual sapinya. Pengeluaran yang besar bagi rumah tangga petani meliputi antara lain, membangun rumah, membeli kendaraan bermotor, biaya anak masuk sekolah baru, dan rencana hajad pernikahan untuk anaknya. Untuk pengeluaran yang tidak relatif besar, petani akan menjual kambing. Hasil dari ternak ayam bisa dikonsumsi sendiri untuk disembelih atau diambil telornya sebagai lauk pauk bagi anggota keluarga atau ketika sedang ada hajatan. Selain dikonsumsi sendiri, ayam terkadang dijual jika ada keperluan relatif kecil.

Selain bertani dan beternak, sebagian besar keluarga petani mempunyai pekerjaan sampingan untuk mencukupi kebutuhan pangan keluarga seperti menjadi buruh bangunan, buruh ayam potong, home industry kecil-kecilan dan juga buruh tani. Upah buruh tani di Desa Pacarejo untuk hari biasa sebesar Rp 50.000/hari dan akan mengalami kenaikan saat musim panen sebesar Rp 60.000 - Rp 75.000/hari. Selain dari bertani, beternak, dan kerja sampingan, masyarakat petani di Desa Pacarejo juga memanfaatkan lahan pekarangan disekitar rumah untuk ditanami berbagai jenis tanaman. Berbagai jenis tanaman yang ditanami antara lain tanaman pangan berupa jagung dan ketela; berbagai tanaman sayur seperti kacang panjang, bayam, lamtoro, dan lain-lain; buah-buahan seperti pisang, pepaya, jambu dan lain sebagainya; tanaman apotik hidup serta tanaman kolonjono sebagai pakan ternak.

2. Akses pangan

Kebutuhan pangan utama keluarga penduduk Desa Pacarejo tercukupi dari hasil pertanian, sedangkan untuk kebutuhan pangan tambahan dan kebutuhan seharihari tersedia di warung-warung maupun toko-toko yang ada di desa tersebut serta terdapat empat buah pasar yang tersebar di Desa Pacarejo. Pasar yang tersebar di Desa Pacarejo merupakan pasar yang hanya buka di hari jawa pasaran seperti Pasar Wage Jonge, Pasar Somremo Dengok, Pasar Legi Kuwon, dan Pasar Pahing Wilayu. Kondisi sarana dan prasarana dalam distribusi pangan yang ada di Desa Pacarejo sangat mendukung. Lokasi warung, toko-toko dan pasar yang menyediakan 
sembako sangat mudah terjangkau sehingga masyarakat tidak mengalami kesulitan dalam mengakses bahan pangan yang dibutuhkan. Selain itu, masyarakat Desa Pacarejo lebih dimudahkan dalam akses bahan pangan dimana terdapat pedagang keliling yang berjualan setiap pagi hari.

\section{Penyerapan pangan}

Pola makan masyarakat Desa Pacarejo biasanya dalam sehari tiga kali makan dengan lauk pauk dan sayuran setiap hari. Untuk masakan sayuran, masyarakat bisa memetik dari pekarangan sendiri, sedangkan lauk berupa tempe, tahu atau daging ayam dan ikan bisa dibeli di pasar, warung atau pedagang sayur keliling. Secara umum masyarakat di Desa Pacarejo tidak mengalami permasalahan dalam pengadaan pangan, baik dari hasil pertanian, penghasilan mereka dari pekerjaan sampingan dan beternak sapi maupun kegiatan ekonomi lainnya sudah sangat mencukupi untuk memenuhi kebutuhan pangan keluarga mereka.

Masyarakat tidak perlu menempuh strategi penghematan pola makan karena sepanjang tahun pola makan mereka tetap sama. Konsumsi pangan selain makanan pokok nasi, petani di Desa Pacarejo juga ada makanan yang menjadi sampingan. Makanan sampingan yang kadang menjadi konsumsi masyarakat adalah adalah tiwul. Untuk makanan yang dikonsumsi musiman sebagai lauk pauk dan camilan masyarakat adalah walang dan enthung. Pemerintah Desa Pacarejo juga mulai memberdayakan masyarakat dengan menggalakkan kembali pangan lokal umbiumbian sesuai dengan anjuran Bupati Gunungkidul. Pemberdayaan masyarakat dengan mengadakan berbagai pelatihan-pelatihan membuat berbagai olahan dari jenis umbi-umbian yang ada di Desa Pacarejo seperti garut, gembili, dan uwi.

Dari penjelasan sebelumnya, maka strategi membangun ketahanan pangan yang dilakukan petani di Desa Pacarejo dapat disederhanakan dalam bentuk tabel berikut:

Tabel 2. Strategi Membangun Ketahanan Pangan Petani

\begin{tabular}{|c|c|}
\hline No. & Strategi Membangun Ketahanan Pangan \\
\hline 1. & $\begin{array}{l}\text { Memaksimalkan lahan pertanian dengan menggunakan pola tanam secara } \\
\text { tumpangsari }\end{array}$ \\
\hline 2. & Ketersediaan bahan makanan utama beras berasal dari hasil pertanian \\
\hline 3. & $\begin{array}{l}\text { Memelihara ternak sapi untuk dimanfaatkan sebagai pupuk kandang } \\
\text { (pupuk organik) yang menyuburkan tanah dan tanaman }\end{array}$ \\
\hline 4. & $\begin{array}{l}\text { Menjadi anggota kelompok tani untuk memperoleh kemudahan dalam } \\
\text { mengakses pupuk bersubsidi }\end{array}$ \\
\hline 5 . & $\begin{array}{l}\text { Memelihara ternak sapi, kambing, dan ayam sebagai tabungan untuk } \\
\text { mencukupi kebutuhan keluarga }\end{array}$ \\
\hline 6. & Kerja sampingan sebagai buruh untuk mencukupi kebutuhan keluarga \\
\hline 7. & $\begin{array}{l}\text { Memanfaatkan lahan pekarangan untuk ditanami berbagai jenis tanaman } \\
\text { untuk mencukupi kebutuhan pangan keluarga dan kebutuhan pakan } \\
\text { ternak }\end{array}$ \\
\hline
\end{tabular}




\begin{tabular}{|l|l|}
\hline 8. & Konsumsi tiwul sebagai makanan selingan pengganti nasi \\
\hline 9. & $\begin{array}{l}\text { Konsumsi jenis makanan musiman seperti entung dan walang pengganti } \\
\text { lauk }\end{array}$ \\
\hline
\end{tabular}

Sumber: Data Primer, 2020

C. Faktor pendukung dan penghambat kearifan local dalam membangun ketahanan pangan

Terdapat dua faktor yang mempengaruhi kearifan lokal dalam membangun ketahanan pangan masyarakat petani di Desa Pacarejo yaitu faktor pendukung dan faktor penghambat.

\section{Faktor pendukung}

Adanya kelompok tani di setiap padukuhan memberikan berbagai fasilitas untuk para petani yang menjadi anggotanya. Kelompok tani dibentuk sebagai wadah untuk memberdayakan petani dalam membahas berbagai permasalahan dalam bidang pertanian. Adanya distribusi pupuk bersubsidi memudahkan petani untuk mengakses dan membeli pupuk kimia melalui kelompok tani di masing-masing padukuhan dengan RDKK (Rencana Definitif Kebutuhan Kelompok) yang telah disediakan oleh Gapoktan.

Selain itu, adanya sosisaliasi atau penyuluhan dalam bidang pertanian selalu diadakan satu bulan sekali di Desa Pacarejo yang menghadirkan berbagai pihakpihak terkait seperti Dinas, BPP, Gapoktan dan Poktan Desa Pacarejo. Sosialiasi tersebut diadakan untuk membahas berbagai permasalahan seputar pertanian yang dihadapi masyarakat petani di Desa Pacarejo. Melalui kelompok tani masyarakat juga diberdayakan dengan memanfaatkan lahan pekarangan mereka untuk ditanami berbagai tanaman seperti sayuran, buah-buahan dan lain sebagainya. Pemanfaatan lahan pekarangan tersebut selalu di sosialisasikan di kelompok tani setiap pertemuan dan adanya dukungan dari pihak desa maupun pihak Dinas Pertanian yang setiap tahunnya memfasilitasi dengan penyediaan bibit tanaman.

\section{Faktor penghambat}

Kendala utama yang dihadapi petani di Desa Pacarejo dalam sistem pertaniannya adalah ketersediaan air. Berbeda dengan pertanian di lahan basah seperti sawah yang terintegrasi dengan jaringan irigasi teknis, pertanian di lahan kering seperti di Pacarejo sangat tergantung dengan curah hujan. Kendala tersebut menjadi penghambat petani yang berkeinginan untuk membudidayakan tanaman selain padi dan palawija. Meskipun petani telah dibekali pengetahuan mengenai masalah pertanian melalui sosialiasi yang diberikan oleh kelompok tani, namun dalam prakteknya hal tersebut akan terbantahkan dengan kondisi alam yang ada.

Dari penjelasan diatas, maka faktor pendukung dan penghambat kearifan lokal dalam membangun ketahanan pangan petani di Desa Pacarejo dapat disederhanakan dalam bentuk tabel berikut:

Tabel 3. Faktor Pendukung dan Penghambat Kearifan Lokal dalam Membangun Ketahanan Pangan

\begin{tabular}{|l|l|l|}
\hline No. & Faktor & Keterangan \\
\hline
\end{tabular}




\begin{tabular}{|l|l|l|}
\hline 1. & Faktor pendukung & $\begin{array}{l}\text { Adanya kelompok tani di setiap padukuhan sebagai } \\
\text { wadah pemberdayaan petani dalam membahas } \\
\text { berbagai permasalahan di bidang pertanian. }\end{array}$ \\
\hline 2. & Faktor penghambat & $\begin{array}{l}\text { Ketersediaan air yang kurang sehingga menghambat } \\
\text { petani yang ingin membudidayakan tanaman selain } \\
\text { padi dan palawija. }\end{array}$ \\
\hline
\end{tabular}

Sumber: Data Primer, 2020

Penelitian ini mengacu pada teori Fungsionalisme Struktural milik Talcott Parsons mengenai konsep AGIL yang dikenal dengan Adaptation (adaptasi), Goal attainment (pencapaian tujuan), Integration (integrasi) dan Latency (pemeliharaan pola). Adaptasi disini adalah Petani di Desa Pacarejo beradaptasi dengan kondisi lahan pertanian yang kering dengan kearifan lokalnya dalam mengelola pertanian yang didasarkan dari hasil pengalaman bertani yang telah dilakukan bertahun-tahun lamanya. Sementara pencapaian tujuan, yakni pertanian yang dilakukan masyarakat petani di Desa Pacarejo adalah untuk bisa mencukupi kebutuhan pangan utama keluarga yaitu ketersediaan beras dalam kurun waktu tertentu. Selain dari hasil pertanian, pemenuhan kebutuhan ekonomi keluarga berasal dari hasil ternak dan bekerja sampingan.

Selanjutnya integrasi, dibentuknya kelompok tani di masing-masing padukuhan sebagai wadah para petani untuk menerima berbagai informasi terkait pertanian. Terakhir pemeliharaan pola, dengan keterbatasan kondisi lahan pertanian, petani tetap melestarikan kearifan lokalnya dalam menjalankan sistem pertanian mereka mulai dari pengolahan lahan hingga penanganan hasil. Melalui kelompok tani masyarakat diberdayakan dengan berbagai informasi dan kegiatan-kegiatan yang menyangkut masalah pertanian, baik sosialisasi atau penyuluhan, kegiatan pelatihan, distribusi pupuk, bibit tanaman, dan lain sebagainya.

\section{PENUTUP}

Sistem pertanian yang dilakukan oleh petani di Desa Pacarejo merupakan hasil dari adaptasi lingkungan alam serta pengalaman bertani yang telah dilakukan bertahun-tahun lamanya. Petani menyesuaikan diri dengan kondisi lahan kering yang bergantung pada curah hujan. Sistem produksi pertanian yang dilakukan oleh petani di Desa Pacarejo terdiri dari beberapa tahapan, antara lain yaitu pengolahan lahan/tanah; jenis tanaman dan cara menanamnya; pola tanam dan pemeliharaan tanaman serta penanganan hasil.

Melalui kearifan lokalnya petani di Desa Pacarejo memiliki strategi-strategi yang dilakukan untuk membangun ketahanan pangan keluarganya. Strategi-strategi tersebut antara lain: memaksimalkan lahan pertanian dengan pola tanam tumpangsari, pemeliharaan ternak sebagai tabungan keluarga dan pemanfaatan pupuk kadang, menjadi anggota kelompok tani untuk kemudahan dalam akses pupuk bersubsidi, bekerja sampingan untuk mencukupi kebutuhan keluarga, pemanfaatan lahan pekarangan untuk dibudidayakan berbagai tanaman pangan.

Terdapat dua faktor yang mempengaruhi kearifan lokal dalam membangun ketahanan pangan masyarakat petani di Desa Pacarejo yaitu faktor pendukung dan faktor 
penghambat. Faktor pendukung disini adalah adanya kelompok tani sebagai wadah pemberdayaan petani dalam membahas berbagai permasalahan dalam bidang pertanian. Sedangkan yang menjadi faktor penghambat dalam sistem pertanian di Desa Pacarejo adalah ketersediaan air. Kendala tersebut menjadi penghambat petani yang berkeinginan untuk membudidayakan tanaman selain padi dan palawija.

Berdasarkan penelitian yang dilakukan di Desa Pacarejo, Kecamatan Semanu, Kabupaten Gunungkidul mengenai kearifan lokal dalam membangun ketahanan pangan petani berikut adalah saran yang dapat diberikan oleh peneliti:

1) Bagi petani di Desa Pacarejo, tetap melestarikan dan mempertahankan kearifan lokal masyarakat yang telah dijalankan selama ini. Serta selalu mengikuti kelompok tani agar mendapatkan berbagai informasi terkait masalah pertanian di Desa Pacarejo. Diharapkan usaha-usaha yang dilakukan petani dapat berjalan menjadi lebih baik.

2) Bagi kelompok tani di Desa Pacarejo, sebagai pihak yang terlibat dalam proses pertanian harus terus berjalan dengan memberikan pendampingan dan pengarahan kepada petani yang diberdayakan agar pertanian di Desa Pacarejo menjadi lebih baik dan petani menjadi lebih berdaya.

Bagi peneliti yang ingin melakukan penelitian sejenis, peneliti menyarankan untuk lebih memahami konsep-konsep kearifan lokal dan ketahanan pangan serta memahami teori yang akan digunakan. Hal ini guna untuk mempermudah menganalisis teori dengan hasil penelitian. Selain itu, kenali informan terlebih dahulu untuk mempermudah pemilihan metode penelitian.

\section{DAFTAR PUSTAKA}

Sukari., B.H.S. Purwana, dan Mudjijono. 2016. Kearifan Lokal Dalam Membangun Ketahanan Pangan Petani Di Desa Lencoh, Selo, Boyolali, Jawa Tengah. Yogyakarta: Balai Pelestarian Nilai Budaya.

Anonim. 2016. Perkembangan Produksi Komoditas Pangan Penting Tahun 2012 - 2016. BKP. Jakarta.

Khalimi, Farik dan Zaenal Kusuma. 2018. Analisis Ketersediaan Air Pada Pertanian Lahan Kering di Gunungkidul Yogyakarta. Jurnal Tanah dan Sumberdaya Lahan 5(1): 721-725.

Ritzer, George dan G. J. Goodman. 2010. Teori Sosiologi Modern. Jakarta: Prenada Media Group.

Sugiyono. 2008. Metode Penelitian Kuantitatif, Kualitatif dan R\&D. Bandung: Alfabeta. 